\title{
PELATIHAN APLIKASI SCHOOLOGY SEBAGAI UPAYA MENYELENGGARAKAN PEMBELAJARAN JARAK JAUH DI SMK SAMUDRA NUSANTARA
}

\section{SCHOOLOGY APPLICATION TRAINING AS AN ORGANIZING EFFORT FOR DISTANCE LEARNING IN SMK SAMUDRA NUSANTARA}

\author{
Irmawati Liliana Kusuma Dewi $^{*}$, Anggita Maharani $^{2}$, Setiyani $^{3}$ \\ (Pendidikan Matematika, FKIP, Universitas Swadaya Gunung Jati, Indonesia) \\ ${ }^{1}$ irmawati.liliana@gmail.com; ${ }^{2}$ anggi3007@yahoo.co.id; ${ }^{3}$ setiyani_0401509081@yahoo.com
}

\begin{abstract}
Abstrak
Tujuan dari kegiatan Pengabdian Kepada Masyarat (PKM) ini adalah untuk meningkatkan kualitas Pembelajaran Jarak Jauh (PJJ), terutama dalam masa pandemi menggunakan Learning Management System (LMS) Schoology. Pemanfaatan e-learning mempermudah guru dalam berinteraksi secara online dengan siswa, mendistribusikan materi, mengunduh daftar hadir, dan membuat evaluasi pembelajaran. Peserta kegiatan PKM LMS-Schoology adalah 18 guru SMK Samudra Nusantara berlokasi di Astanajapura Kabupaten Cirebon. Metode dalam pengabdian ini terdiri dari tiga tahap, 1) tahap pra pelatihan yaitu merancang modul tutorial singkat, proses pelatihan, dan angket; 2) tahap pelatihan yaitu pengenalan LMS Schoology dan pembuatan akun; 3) tahap evaluasi yaitu tanggapan guru terhadap pelatihan melalui angket. Selama pelatihan berlangsung, peserta sangat antusias dalam menyimak materi dan aktif berdiskusi. Berdasarkan hasil angket respons peserta terhadap pelatihan LMS-Schoology diperoleh rata-rata dari aspek pemateri sebesar $76.23 \%$ termasuk kategori kuat. Kegiatan pendampingan ini memberikan nilai tambah bagi guru dalam penguasaan Ipteks dan dapat digunakan sebagai platform pembelajaran yang efektif.
\end{abstract}

Kata Kunci : Schoology; Pembelajaran Jarak Jauh; Blended Leaning

\begin{abstract}
The purpose of this Community Service (PKM) activity is to improve the quality of Distance Learning (PJJ), especially during a pandemic using a Learning Management System (LMS) - Schoology. The use of e-learning makes it easier for teachers to interact online with students, distribute materials, download attendance lists, and make learning evaluations. Participants in the LMS-Schoology PKM activity were 18 SMK Samudra Nusantara teachers located in Astanajapura, Cirebon Regency. The method in this service consists of three stages, 1) the pre-training stage, namely designing a short tutorial module, the training process, and a questionnaire; 2) the training stage, namely the introduction of LMS Schoology and creating an account; 3) the evaluation stage, namely the teacher's response to training through a questionnaire. During the training, the participants were very enthusiastic in listening to the material and had active discussions. Based on the results of the questionnaire responses of participants to the LMS-Schoology training, it was obtained an average of $76.23 \%$ from the speaker aspect, including the strong category. This mentoring activity provides added value for teachers in mastering science and technology and can be an effective learning platform.
\end{abstract}

Keywords: Schoology, Distance Learning, Blended Learning

\section{PENDAHULUAN}

Indonesia dan mayoritas negara di dunia sedang menghadapi permasalahan yang sama yaitu menghentikan laju penularan virus SARSCOV-19 atau yang lebih dikenal virus corona. Beberapa wilayah terpaksa melakukan lock down, semua aktivitas masyarakat dilakukan di rumah. Presiden Republik Indonesia Bapak Joko Widodo mengimbau agar seluruh rakyatnya 
bekerja dari rumah, belajar dari rumah dan beribadah di rumah saja (https://headtopics.com/). Pandemi yang disebabkan virus corona membawa dampak negatif di segala sektor kehidupan, begitu pula dunia pendidikan tidak luput dari dampak negatif tersebut. Berdasarkan surat edaran Menteri Pendidikan dan Kebudayaan Republik Indonesia No. 4 Tahun 2020, tentang pelaksanaan kebijakan pendidikan dalam masa darurat penyebaran corona virus disease (covid-19) maka pembelajaran dilaksanakan dari rumah secara daring.

Guru, siswa dan orang tua dituntut segera beradaptasi melaksanakan Pembelajaran Jarak Jauh (PJJ) dengan Belajar dari Rumah (BDR). Siswa sebagai ujung tombak kemajuan suatu bangsa harus mendapatkan PJJ yang berkualitas agar tercipta generasi emas di masa yang akan datang (Pujiasih, 2020). Setiap hari, guru membuat video pembelajaran yang menarik, berorientasi pada siswa dan memberikan tugas secara online yang tidak memberatkan siswa. Beberapa aplikasi pembelajaran online dapat digunakan untuk membuat video yang interaktif, misalnya powtoon, video scribe, Camtasia studio, bandicam, kinemaster, inshoot, macromedia flash, dan masih beragam jenis aplikasi lain. Beberapa evaluasi online juga tersedia secara gratis dan bisa diakses siapa saja, misalnya google form, quizizz, kahoot, maupun evaluasi pembelajaran online berbasis website. Platform pembelajaran yang lengkap juga dapat digunakan selama PJJ diantaranya Google Classroom, Edmodo, Moodle, Schoology, maupun platform lain berbasis Learning Management System (LMS) yang dikembangkan oleh institusi Pendidikan. Untuk memperlancar arah komunikasi baik guru ke siswa ataupun guru ke orangtua dapat dengan mudah menggunakan whatsapp group.

Learning Management System (LMS) adalah sebuah aplikasi software yang dapat membantu yang dapat membantu merencanakan, mengimplementasikan sebuah proses pembelajaran. LMS memungkinkan pemilik atau pembuat course (kelas) untuk mengelola, menyampaikan, dan memonitor para muridnya. LMS memadukan antara kursus tradisional dengan media digital dan alat interaktif meliputi kursus online, virtual live sessions dan forum diskusi. Salah satu e-learning berbasis LMS yang menawarkan pembelajaran secara gratis dan berbentuk seperti web sosial adalah schoology. Platform inovatif ini terinspirasi oleh media sosial facebook, dikembangkan pada tahun 2009 di New York dan peruntukkannya untuk Pendidikan (Salim et al., 2020). Beberapa fitur-fitur sudah tersedia dalam schoology seperti recent activity, course dashboard, groups, resources (Suchaina, 2018). 
Fitur recent activity berisi tentang umpan kiriman yang berhubungan dengan guru, courses (kursus) dan groups yang guru kelola. Fitur course dashboard berisi courses (kursus) dimana guru dapat menyimpan konten pembelajaran, materi, file, tugas, penilaian, serta berkomunikasi dengan siswa. Fitur groups mengakomodir komunikasi yang mungkin saja tidak hanya antara guru dan siswa, tapi dapat melibatkan orangtua siswa. Fitur resources merupakan tempat di mana semua materi pembelajaran disimpan, dalam bentuk file ataupun guru dapat menghubungkan ke aplikasi lain seperti Google Drive dan Microsoft One Drive.

Schoology juga tersedia dalam bentuk aplikasi yang dapat diunduh, dan dapat digunakan melalui smartphone sehingga mempermudah siswa dan guru untuk menggunakannya. Berdasarkan hasil penelitian (Rahmadoni et al., 2020), spesifikasi alat pembelajaran yang ada pada schoology lebih lengkap dibandingkan dengan Edmodo atau Moodle. Schoology juga merupakan platform pembelajaran yang efektif terhadap kemampuan komunikasi matematis siswa (Setiyani, 2019). Laman schoology dapat diakses melalui www.schoology.com.

SMK Samudra Nusantara yang berlokasi di Astanajapura Kabupaten Cirebon merupakan salah satu sekolah kejuruan yang memiliki fasilitas cukup lengkap. Pembelajaran secara daring dilaksanakan memanfaatkan whatsapp group dan google classroom. Siswa yang tidak bisa mengakses keduanya, dapat mengambil dan menyerahkan tugas ke sekolah dengan protokol kesehatan yang ketat. Dalam pelaksanaannya, pemanfaatan whatsapp group dan google classroom hanya sebatas asynchronous. Siswa dan guru tidak terlibat secara langsung dalam proses diskusi \& tanya jawab. Padahal potensi IT yang dimiliki oleh SMK Samudra Nusantara, memungkinkan pembelajaran syncronous. Salah satu platform yang dapat dimanfaatkan adalah Schoology. Melalui pelatihan pemanfaatan Schoology, diharapkan guru-guru SMK Samudra Nusantara mendapatkan pengetahuan praktis tentang penggunaan LMS Schoology.

\section{METODOLOGI}

Mengenalkan schoology serta bagaimana memanfaatkan dengan maksimal semua fitur yang ada dalam proses pembelajaran jarak jauh adalah tujuan utama pelatihan ini dilakukan.. Peserta pelatihan adalah guru-guru SMK Samudra Nusantara, yang berjumlah 18 orang. Pelatihan ini dibantu oleh seorang teknisi IT, dengan tujuan mengantisipasi apabila terjadi 
kendala terkait dengan sistem. Adapun metode pelatihan ini dibagi menjadi 3 tahap yaitu pra pelatihan, pelatihan dan evaluasi. Aktivitas yang dilakukan oleh tim pengabdian dalam setiap tahapannya sebagai berikut :

\section{Tahap Pra Pelatihan}

Pada tahap ini tim melakukan observasi dan wawancara dengan beberapa guru untuk mengetahui kebutuhan di lapangan dan melihat bagaimana PJJ yang sedang diterapkan. Selanjutnya, tim berdiskusi dengan kepala sekolah untuk menentukan waktu dan tempat pelatihan. Tahapan pra pelatihan yang lain adalah merancang materi pelatihan berupa modul tutorial singkat, merancang proses bagaimana pelatihan dilakukan, dan menyusun angket untuk mengetahui kepuasan guru setelah penelitian.

\section{Tahap Pelatihan}

Pada tahap ini tim melakukan pelatihan sesuai dengan tempat dan waktu yang telah ditentukan. Sesi pelatihan terdiri dari tiga bagian yaitu pengenalan LMS Schoology, pembuatan akun student yang terhubung pada akun guru/Instructor, dan pembuatan akun guru agar dapat membuat kelas virtual berdasarkan mata pelajaran yang diajarkan. Diskusi antar guru dan tim bersifat integrasi, artinya apabila guru sewaktu-waktu ada kesulitan dapat langsung bertanya pada tutor selama pelatihan berlangsung

\section{Tahap Evaluasi}

Setelah sesi pelatihan, selanjutnya guru diminta menuliskan tanggapan pelatihan ini dengan mengisi angket yang telah disediakan. Tujuannya adalah untuk mengetahui kebermanfaatan pelatihan LMS Schoology, dan mengantisipasi kekurangan yang terjadi pada pelatihan serupa selanjutnya. Angket ini terdiri dari lima aspek yaitu pemateri, materi, suasana, schoology, dan kesan penggunaan schoology.

Tabel 1. Klasifikasi Koefisien Presentase Angket

\begin{tabular}{cc}
\hline Nilai & Interprestasi \\
\hline $0 \%-20 \%$ & Sangat Lemah \\
$21 \%-40 \%$ & Lemah \\
$41 \%-60 \%$ & Cukup \\
$61 \%-80 \%$ & Kuat \\
$81 \%-100 \%$ & Sangat Kuat \\
\hline
\end{tabular}




\section{PEMBAHASAN}

Pelatihan LMS-Schoology dilaksanakan pada tanggal 25 Agustus 2020, bertempat di aula SMK Samudra Nusantara Kabupaten Cirebon dan melibatkan 18 guru. Kegiatan ini dilaksanakan oleh tim yang sudah memahami tugasnya masing-masing, terdiri dari 2 dosen pemateri, 1 orang teknisi, dan 1 orang dosen sebagai asisten untuk membantu peserta jika mengalami kendala saat praktik membuat akun schoology. Berdasarkan tahapan kegiatan yang telah diuraikan pada metode pelatihan, setelah tahap pra pelatihan maka tahap selanjutnya adalah peserta mengikuti tahap pelatihan. Pada awal kegiatan pelatihan, tim menjelaskan tentang bagaimana membuat akun guru/instructor, membuat course, menambah course member, menentukan course material yang akan digunakan. Beberapa kegiatan dalam pelatihan dapat dilihat pada Figur 1.
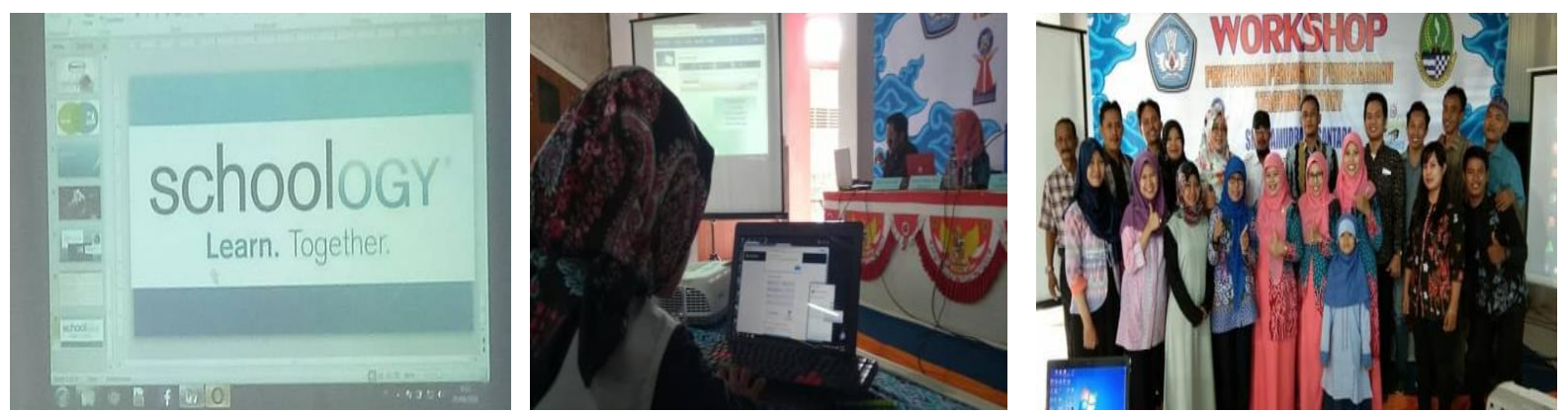

Figur 1. Pelatihan Schoology di SMK Samudra Nusantara

Setelah pemaparan materi oleh tim, guru membuat akun di LMS Schoology. Adapun kode kelas beberapa kelas virtual yang dibuat oleh guru dapat dilihat pada Tabel 2 berikut :

Tabel 2. Contoh Kode Kelas Schoology yang dibuat peserta pelatihan

\begin{tabular}{llc}
\hline No & Nama Guru & Kode Kelas \\
\hline 1. & Agus Santoso, S.Pd & $53 Q 2-676 F-R 8 C P Z$ \\
2. & Dian Puspitawati, S.Pd & $9 R C W-J D 2 N-S 8 J R 6$ \\
\hline
\end{tabular}

Sebanyak 10 dari keseluruhan guru yang berjumlah 18 orang, berhasil membuat kelas virtual pada mata pelajarannya masing-masing. Contoh kelas virtual yang dibuat guru tampak seperti Figure 2. Setelah guru membuat kelas-kelas virtual pada mata pelajaran masingmasing, tim memberikan angket respons terhadap kegiatan pelatihan ini. Angket berupa pernyataan-pernyataan yang memiliki 4 kemungkinan jawaban yaitu sangat tidak setuju, tidak setuju, setuju, sangat setuju. Selanjutnya angket dianalisis, dan hasil tanggapan guru terhadap pelatihan LMS Schoology dapat dilihat pada Tabel 3. 


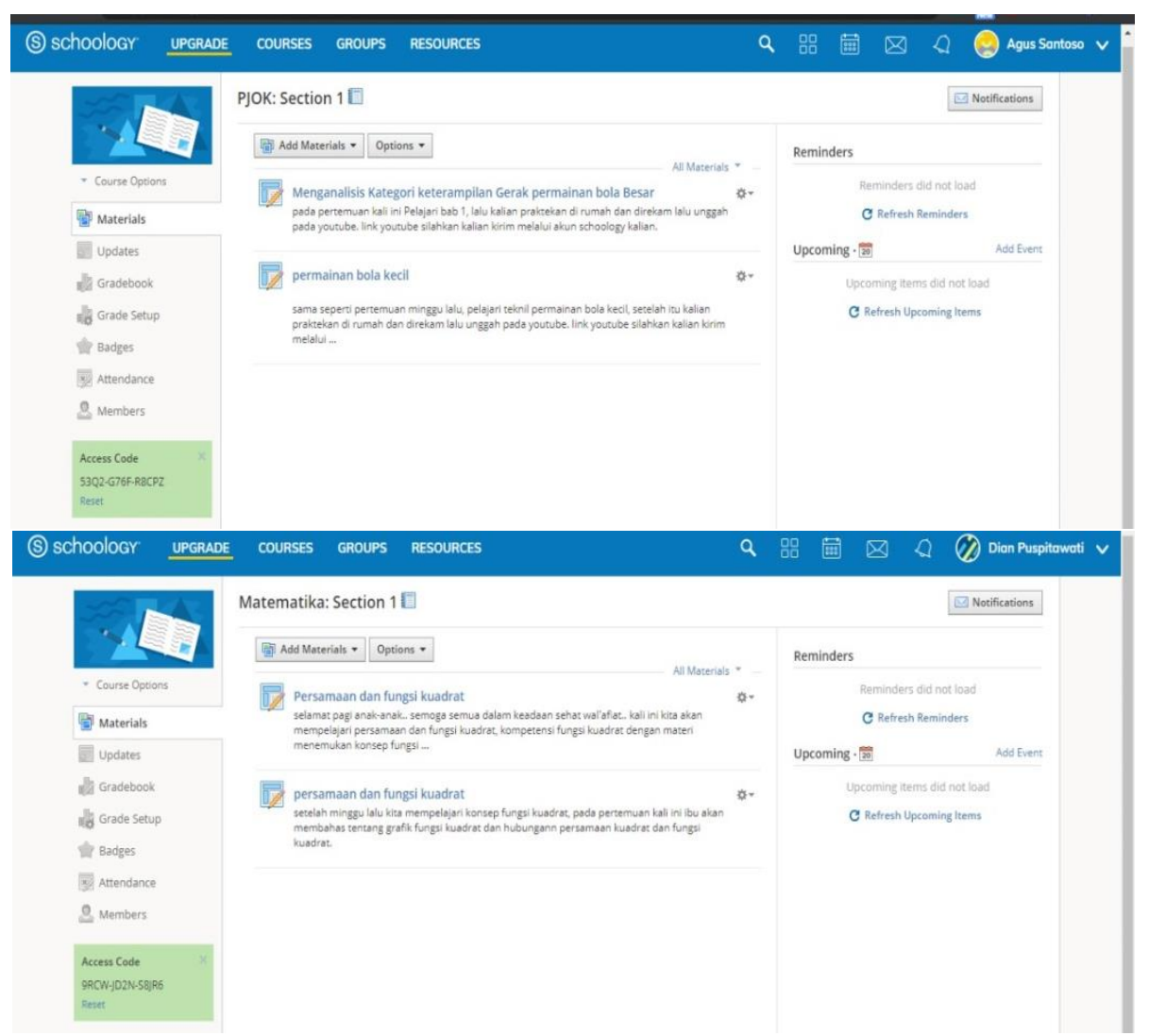

Figur 2. Produk Kelas Schoology yang Dibuat oleh Peserta Pelatihan

Tabel 3. Tanggapan guru terhadap pelatihan LMS Schoology di SMK Samudra Nusantara

\begin{tabular}{|c|c|c|c|c|c|c|}
\hline No & Pernyataan & STS & $T S$ & $S$ & $S S$ & $\%$ \\
\hline \multicolumn{7}{|c|}{ Pemateri } \\
\hline 1 & Menguasai materi & & & 13 & 4 & $81 \%$ \\
\hline 2 & Komunikatif & & & 16 & 1 & $76 \%$ \\
\hline 3 & Menarik & & 2 & 13 & 2 & $75 \%$ \\
\hline 4 & Presentasi audio visualnya menatik & & 3 & 13 & 1 & $72 \%$ \\
\hline 5 & Penjelasannya terstruktur & & 2 & 13 & 2 & $75 \%$ \\
\hline 6 & Memberi kesempatan diskusi & & 1 & 13 & 3 & $78 \%$ \\
\hline \multicolumn{7}{|c|}{ Materi } \\
\hline 7 & Sasaran/tujuannya jelas & & & 11 & 6 & $84 \%$ \\
\hline 8 & Relevan dengan program sekolah & & & 7 & 10 & $90 \%$ \\
\hline 9 & Bermanfaat untuk siswa/guru & & & 6 & 11 & $91 \%$ \\
\hline 10 & Sesuai dengan harapan & & 1 & 7 & 9 & $87 \%$ \\
\hline 11 & Cakupan materinya memadai & & 1 & 10 & 6 & $82 \%$ \\
\hline 12 & Sesuai dengan perkembangan & & & 8 & 9 & $88 \%$ \\
\hline \multicolumn{7}{|c|}{ Suasana } \\
\hline 13 & Membosankan & 1 & 16 & & & $76 \%$ \\
\hline 14 & Tepat waktu & & 4 & 9 & 4 & $75 \%$ \\
\hline 15 & Nyaman & & & 13 & 4 & $81 \%$ \\
\hline 16 & Peserta workshop aktif & & 2 & 13 & 2 & $75 \%$ \\
\hline 17 & Ketersediaan waktu yang cukup & 1 & 7 & 7 & 2 & $65 \%$ \\
\hline \multicolumn{7}{|c|}{ Blended Learning \& Schoology } \\
\hline 18 & Sudah mengetahui sebelum workshop & 1 & 11 & 5 & & $69 \%$ \\
\hline
\end{tabular}




\begin{tabular}{|c|c|c|c|c|c|c|}
\hline No & Pernyataan & STS & $T S$ & $S$ & $S S$ & $\%$ \\
\hline 19 & Sudah menggunakan sebelum workshop & 2 & 14 & 1 & & $76 \%$ \\
\hline 20 & Memfasilitasi berkembangnya siswa & & & 12 & 5 & $82 \%$ \\
\hline 21 & Efektif untuk dilakukan & & 1 & 10 & 6 & $82 \%$ \\
\hline 22 & Tertarik untuk mengaplikasikan & & 1 & 9 & 7 & $84 \%$ \\
\hline 23 & Pembelajaran di sekolah sudah berbasis e-learning & 1 & 4 & 11 & 1 & $68 \%$ \\
\hline \multicolumn{7}{|c|}{ Kesan Penggunaan Schoology } \\
\hline 24 & Mudah dimengerti & & 2 & 13 & 2 & $75 \%$ \\
\hline 25 & Menarik & & 1 & 12 & 4 & $79 \%$ \\
\hline 26 & Mudah untuk digunakan & & 2 & 12 & 3 & $76 \%$ \\
\hline 27 & Dapat meningkatkan aktivitas dan motivasi belajar siswa & & 1 & 10 & 6 & $82 \%$ \\
\hline 28 & Lebih baik daripada aplikasi e-learning yang lain & & 1 & 13 & 2 & $72 \%$ \\
\hline \multicolumn{2}{|r|}{ Rata-rata } & & & & & $78.3 \%$ \\
\hline
\end{tabular}

Hasil angket respons peserta terhadap pelatihan LMS-Schoology diperoleh rata-rata dari beberapa aspek yang diamati. Berdasarkan 1) pemateri memiliki rata-rata sebesar $76.17 \%$ termasuk kategori kuat, 2) aspek materi yang disampaikan diperoleh rata-rata 87\% termasuk kategori sangat kuat, 3) aspek suasana pelatihan, diperoleh rata-rata $74.41 \%$ termasuk kategori kuat, 4) aspek Blended learning dan schoology, rata-rata penilaian peserta sebesar 76.83\% termasuk kategori kuat, dan 5) kesan penggunaan schoology termasuk kategori kuat, karena memperoleh rata-rata persentase sebesar $77 \%$. Hasil kegiatan ini sejalan dengan Mulyono dan Asmara (2020) bahwa schoology dapat membantu memberikan pemahaman terhadap pemanfaatan IT yang diintegrasikan pada pembelajaran bagi guru dan memberikan apresiasi positif serta dukungan dari semua unsur sekolah.

Pada aspek pemateri, penguasaan materi memiliki persentase $81 \%$, sedangkan kebermanfaatan materi pelatihan bagi guru/siswa memiliki persentase $91 \%$ pada aspek materi. Hal tersebut menunjukkan bahwa materi pelatihan dapat diterima dengan baik oleh para peserta pelatihan. Peserta sangat antusias mengikuti pelatihan schoology, datang tepat waktu, dan menghasilkan luaran berupa akun schoology (Rosy et al., 2018). Pesertapun merasakan suasana pelatihan yang nyaman dengan ketersediaan fasilitas IT yang lengkap, ditunjukkan dengan hasil angket sebesar $81 \%$. Persentase ketertarikan peserta pelatihan untuk mengaplikasikan penggunaan schoology sangat tinggi ditunjukkan dengan nilai $84 \%$. Keyakinan peserta pelatihan jika penggunaan schoology dapat meningkatkan aktivitas dan motivasi belajar siswa juga sangat tinggi dengan persentase sebesar 82\%. Hal ini sesuai dengan pendapat Friansah dan Yanto (Friansah dan Yanto, 2020), yang menyatakan bahwa pelatihan schoology menambah pengetahuan bagi guru dan dapat diterapkan serta diakses dengan mudah kapanpun dan dimanapun. Penguasaan IT tidak hanya diperuntukkan untuk 
guru yang mengajar teknologi informasi saja, tetapi juga untuk guru mata pelajaran lain (Barustyawati et al., 2019) termasuk guru matematika.

\section{KESIMPULAN DAN SARAN}

Kegiatan pelatihan LMS-Schoology bagi guru SMK Samudra Nusantara berjalan sesuai dengan rencana. Indikator ketercapaian kegiatan ini diantaranya peserta memahami cara menggunakan schoology, dapat membuat kelas-kelas virtual, dapat mendistribusikan sumber belajar, berinteraksi secara online dengan siswa dan membuat evaluasi. Peserta antusias dalam kegiatan diskusi, hal ini dibuktikan dengan banyaknya pertanyaan-pertanyaan dan seluruh peserta mencoba menggunakan schoology. Selain itu peningkatan Iptek pada masyarakat berupa pemanfaatan LMS-Schoology oleh guru dapat meningkatkan kualitas pembelajaran terutama di masa pandemi ini.

\section{UCAPAN TERIMAKASIH}

Tim PkM mengucapkan terima kasih kepada Lembaga Pengabdian Masyarakat (LPM) Univeritas Swadaya Gunung Jati yang telah memberikan hibah dengan nomor kontrak 02/LPM-UGJ/VII/2020 dan SMK Samudra Nusantara Astanajapura selaku mitra pengabdian masyarakat.

\section{REFERENSI}

Asmara, Y., dan Mulyono, D. (2020). Workshop Pemanfaatan E-Learning Schoology dalam Pembelajaran pada GFuru SMP Bakti Ibu 11 Lubuklinggau. JURNAL CEMERLANG: Pengabdian Pada Masyarakat, 2(2): 173-183.

Barustyawati, A. A. S., Suarcaya, P., Adijaya, M. A., dan Wage, I. P. N. (2019). Pengembangan Kelas E-Learning dengan Aplikasi Schoology di SMA PGRI Seririt dan SMA Saraswati Seririt. Seminar Nasional Pengabdian Kepada Masyarakat, 4: 794801.

Friansah, D., dan Yanto, Y. (2020). Pelatihan Learning Management System-Schoology Bagi Guru MGMP Matematika SMA/SMK Kabupaten Musi Rawas. JURNAL CEMERLANG: Pengabdian Pada Masyarakat, 2(2): 184-195.

Pujiasih, E. (2020). Membangun generasi emas dengan variasi pembelajaran online di masa pandemi covid-19. Ideguru: Jurnal Karya Ilmiah Guru, 5(1): 42-48.

Rahmadoni, J., Arifnur, A. A., dan Wahyuni, U. M. (2020). Penerapan schoology sebagai learning management system bagi guru SMAN 1 Sutera. Jurnal Hilirisasi IPTEKS, 3(2): 129-137. 
Riduwan, M. B. A. (2003). Dasar-dasar statistika. Bandung: Alfabeta.

Rosy, B., Ranu, M. E., Nugraha, J., dan Handini, H. T. (2018). Pelatihan Media Pembelajaran Berbasis E-Learning, Schoology Bagi Guru SMK Program Keahlian Administrasi Perkantoran Di Kabupaten Jombang Jawa Timur. Jurnal Pemberdayaan Masyarakat Madani (JPMM), 2(2): 174-185.

Salim, S., Jazuli, L.O.A., Nurhayati, dan Saputra, H. N. (2020). Pelatihan Penggunaan Platform Aplikasi E-learning Schoology Pada Guru SMA. Jurnal Pengabdian Dan Peningkatan Mutu Masyarakat, 1(2): 151-158.

Setiyani, S. (2019). Blended Learning: The Effectiveness of Schoology Based E-Learning on Mathematic Communication Abuility. Jurnal Kependidikan: Penelitian Inovasi Pembelajaran, 3(2): 143-155.

Suchaina, S. (2018). Pembelajaran E-Learning Berbasis Schoology.: Jurnal Pendidikan, Pembelajaran Dan Bimbingan Dan Konseling, 6(1): 47-54.

Pratiwi, P. S. (2020, Maret 15). Jokowi Imbau Masyarakat Bekerja dan Beribadah di Rumah. Head Topics Indonesia. Diakses dari Https://Headtopics.Com. 